\title{
Circular Economy Initiatives through Energy Accounting and Sustainable Energy Performance under Integrated Reporting Framework
}

\author{
Akeel Hamza Almagtome \\ Faculty of Administration and Economics, \\ University of Kufa, Najaf, Iraq. \\ Corresponding author: akeelh.alhasnawi@uokufa.edu.iq \\ Ahmed Jassim Al-Yasiri \\ Faculty of Administration and Economics, \\ University of Kufa, Najaf, Iraq. \\ E-mail: ahmedj.alyaseri@uokufa.edu.iq \\ Raed Saiad Ali \\ Faculty of Administration and Economics, \\ University of Misan, Misan, Iraq. \\ E-mail:raid1982100@gmail.com

\section{Hasan Latif Kadhim} \\ Faculty of Administration and Economics, \\ University of Kufa, Najaf, Iraq. \\ E-mail: hasan.latef@uokufa.edu.iq

\section{Heider Nima Bekheet} \\ Faculty of Administration and Economics, \\ University of Kufa, Najaf, Iraq. \\ Email: heider.nima@uokufa.edu.iq
}

(Received August 15, 2019; Accepted July 8, 2020)

\begin{abstract}
The financial reporting plays a significant role in sustainable development, as it contributes greatly to providing the information required to assess sustainable development performance. In order to achieve the sustainable development, accurate information should be provided to stakeholders on the energy consumed and the impact of energy consumption on the environment. Information on sustainable energy performance needs providing both of financial and non-financial information. However, the traditional financial reporting system is unable to provide information that helps measure and promote sustainable energy performance, as the current accounting system provides financial information only. It is therefore important to adopt an appropriate reporting framework to support the evaluation of sustainable energy performance. This paper proposes an approach to the measure the sustainable energy performance based on the integrated reporting framework. A unique feature of the approach is the selection of corporate energy performance indicators that cover both financial and non-financial information. This paper therefore sets out indicators for assessing sustainable energy performance based on the Integrated Reporting Framework. Furthermore, the application of the indicators proposed in this paper helps regulators and economic policy makers to develop sustainable development strategies at national level. Moreover, the adoption of the proposed indicators can provide accurate information on the real and future of sustainable energy in the country.
\end{abstract}

Keywords- Energy accounting, Sustainable energy, Energy performance, Accounting system, Integrated reporting framework. 
International Journal of Mathematical, Engineering and Management Sciences

Vol. 5, No. 6, 1032-1045, 2020

https://doi.org/10.33889/IJMEMS.2020.5.6.079

\section{Introduction}

In recent decades, rapid global economic growth has become a major burden on the majority of countries in the world concerned about environmental issues and the protection of natural resources. As a result, many countries and major international companies have begun to focus on energy conservation and emission reduction in order to achieve sustainable development (Almagtome et al., 2019). At the same time, many countries and professional accounting institutions have begun to realize the importance of accounting for energy resources (Su, 2019). Measuring energy performance is one of the most effective methods of providing information for decision-making on the extent of dependence on fossil fuels and improving the competitiveness of industrial companies, as well as improving the long-term security of energy sources. Improving the level of sustainable energy performance helps to reduce emissions of greenhouse gases that are harmful to the environment and is a key element in achieving the objectives of sustainable development at the micro and macro levels (economic units and countries).

In this context Ang et al. (2010) demonstrate that efficient energy performance in any country plays a key role in achieving the primary energy policy objectives of energy stability, economic competitiveness and sustainability. It is therefore evident that the measurement of energy performance will receive increasing attention from many countries around the world. At the other hand, multinational corporations have been one of the key pillars of social and environmental issues due to their practices and goods aimed at increasing profits in the short term, irrespective of the adverse impact on the environment. There is a rise in societal concerns about the damage these businesses pose to the general population, as well as how the social and environmental factors would threaten the survival of these businesses in the long term. It is therefore the responsibility of companies to provide stakeholders with the information necessary to ensure the continuity of economic activity while preserving natural resources and contributing to sustainable development. In order to achieve this objective, companies use a variety of tools to express the efficiency of natural resource management and, in particular, energy consumption.

The financial reporting system is one of the traditional methods used by companies to demonstrate the value and performance of the company through annual financial reports. Nevertheless, financial reports typically concentrate on presenting financial information related to sustainable energy management, and the financial report does not contain any non-financial details related to the social and environmental effects of the company's economic activities. The explanation for this is due to the complexity of the accounting and dual-entry information system. The accounting system records only transactions and units that can be expressed in a financial form, either as non-financial information, descriptive or in a quantity measured in non-monetary units that cannot be recorded in the accounting books. Some researchers have tried to provide models for calculating and disseminating knowledge on energy use and how to control energy sources (Hong et al., 2019; Mangla et al., 2020; Rehman Khan and Yu, 2020). The GRI guidelines are a set of indicators that assess the degree of economic, social and environmental success as part of the Sustainability Report (Khaghaany et al., 2019). Nonetheless, this method of reporting did not give the study on renewable energy efficiency the attention it deserved, as well as its incompatibility with the essence of the conventional financial reporting structure currently in place (Ali et al., 2019a). In the same sense, the Integrated Reporting System is one of the recent attempts to include in the consolidated report the annual report on both financial and non-financial details and to explain the relationship between the various forms of resources used in economic activity. The adoption of the Integrated Reporting framework therefore involves a fundamental reform in the conventional accounting system to accommodate both financial and non-financial information. 
International Journal of Mathematical, Engineering and Management Sciences

Vol. 5, No. 6, 1032-1045, 2020

https://doi.org/10.33889/IJMEMS.2020.5.6.079

Unexpectedly, there is almost a minimal body of literature on sustainable energy performance indicators and how they can be measured and disclosed in the financial statements. The aim of this paper is to shed light on the requirements for implementing energy accounting using the traditional financial reporting system currently in place and to assess the role of the integrated reporting framework in reducing the financial reporting gap. The paper also aims to propose a set of performance indicators for sustainable energy by drawing on an integrated reporting framework through which relevant information can be provided to stakeholders on energy efficiency in organizations.

\section{Circular Economy Initiatives and Sustainable Energy Performance}

The circular economy aims to conserve resources in the economy for as long as possible. A number of ecological initiatives are being used to achieve this, such as reducing fossil energy consumption, recycling of waste, reducing emissions, and so on (Karstensen et al., 2020). Renewable energy is the largest part of the activity of the circular economy today because it is the main driver of the global economy. The circular economy provides opportunities for large companies to improve their business activities while promoting sustainable development objectives (Kravchenko et al., 2019). Implementation of circular economy initiatives requires the adoption of strategies that, on the one hand, benefit the environment and the economy and, on the other, benefit the financial and accounting aspects. The main challenge for companies is to develop their accounting and financial systems in order to meet the requirements of the circular economy in general and to enhance the performance of sustainable energy as one of the most important pillars of the circular economy. An accounting information system that meets the needs of decision-making in the field of planning, supervision and decision-making should be in place to implement circular economy initiatives, whether related to sustainable energy management or sustainable development. The energy accounting system should therefore be developed in line with the needs of the assessment of sustainable energy performance.

\subsection{Energy Accounting System}

Energy accounting is an information system used to calculate, analyze and convey information on energy use on a daily basis in the organization's activities. The objective of this system is to improve the energy efficiency of the organization as well as to monitor the environmental impacts of all types of energy consumption activities. Energy accounting is a new accounting branch that combines accounting theories and methods with economics in order to provide the information needed for efficient energy management and the promotion of fully sustainable energy. The objectives of energy conservation and the reduction of harmful gas emissions are the principles for this accounting branch, in line with the accounting standards issued by the International Accounting Standards Board. Although traditional accounting systems measure only financial information, the energy accounting system measures and reports on the organization's energy conservation and pollution reduction activities in order to achieve sustainable economic development and the protection of natural resources (Goh and Ang, 2019). According to Su (2019), energy accounting systems are committed to providing useful information in order to achieve three basic functions:

\section{- Energy Management and Control}

This function includes managing and controlling the cost of energy consumption within the organization using equipment, modern technology and energy investment, as well as using advanced management methods to achieve energy efficiency objectives.

\section{- Treatment and Prevention of Toxic Substances}

This function means that energy accounting is concerned with providing an understanding of the 
International Journal of Mathematical, Engineering and Management Sciences

Vol. 5, No. 6, 1032-1045, 2020

https://doi.org/10.33889/IJMEMS.2020.5.6.079

economic, environmental and social benefits of the company as a result of controlling energy costs and the percentage of pollutants resulting from its activities. This position requires the accounting system to provide stakeholders with information on the economic, environmental and social benefits that the company provides to society as part of its commitment to sustainable development and energy efficiency (Figure 1, prepared by authors based on Su, 2019)

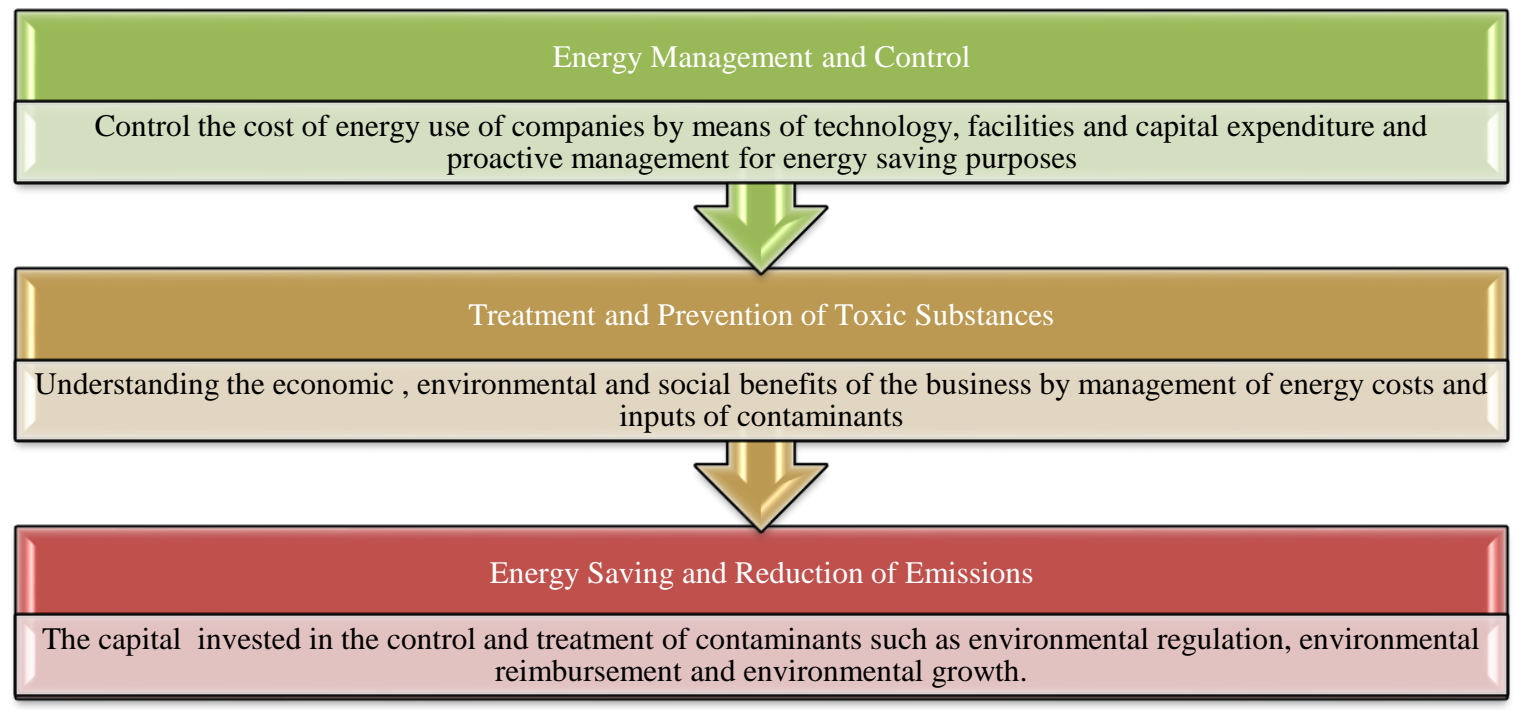

Figure 1. Functions of energy accounting

\section{- Energy Saving and Reduction of Emissions}

This function means the disclosure of information, the company's investments in pollution management and prevention, such as environmental management systems, environmental incentives and environmental governance, etc. Irrespective of the nature of the information that the energy accounting system is expected to provide, this system follows the same steps as the accounting cycle in traditional accounting systems. Energy accounting therefore includes all necessary accounting procedures for measuring and controlling energy costs, as well as recording expenditure on the prevention and disposal of pollutants. In addition, energy accounting is concerned with providing information on the benefits of environmental protection activities and reducing the level of energy consumption emissions. An efficient energy accounting system can encourage companies to pay attention to measuring the social and environmental activities of the organization in conjunction with the goal of maximizing profits.

Under the traditional financial reporting system, disclosure of energy information is a product of the company's day-to-day accounting activities. Information on energy efficiency in the three functions referred to above is disclosed in the company's annual report or in separate reports. Companies are obliged to disclose information related to energy applications, energy assets, energy consumption as well as energy revenue disclosure, energy consumption taxes and fees, environmental protection fees and total energy expenditure. However, the problem facing the traditional financial reporting system in the field of energy accounting is the disclosure of energyrelated issues that cannot be measured in monetary units, such as the volume of pollutants, the 
International Journal of Mathematical, Engineering and Management Sciences

Vol. 5, No. 6, 1032-1045, 2020

https://doi.org/10.33889/IJMEMS.2020.5.6.079

amount of emissions, the amount of energy consumed or supplied, the amount of recycled materials and the amount of renewable energy used in the activities of the company. This type of information requires changes to the financial reporting system to meet the energy accounting needs for nonfinancial information.

\subsection{Energy Performance Measurement}

Energy is the main source of economic development in the world and the basis for people's development and prosperity. However, as a result of massive population growth and economic and technical developments, the energy crisis and the environmental impacts of fossil energy consumption have become more dangerous globally. According to the Estimates of the International Energy Organization 2017, oil is the main energy source in the world, global oil consumption is $30.6 \%$, followed by coal consumption by $26.9 \%$, and natural gas consumption by $22.6 \%$. Total fossil energy sources (conventional energy sources) accounted for $80.1 \%$ of global energy consumption in 2017. Whereas the remaining renewable energy consumption is $19.9 \%$, as shown in Table 1 . The careful review of Table 1 data reveals a decrease in dependence on traditional energy sources in recent years compared to the level of energy consumption in 2000. Global oil consumption decreased by $6 \%$ and the consumption of other renewable energy sources increased by $2 \%$. This result shows the global trend towards sustainable energy consumption compared to the gradual abandonment of traditional energy sources. Moreover, the major industrial companies in the world are the main energy consumers, and the low consumption of traditional energy sources means an increase in the interest of these companies in sustainable energy.

Table 1. The world energy consumption (2000-2017)

\begin{tabular}{|c|c|c|c|c|c|c|c|}
\hline year & \% Oil & $\begin{array}{c}\text { \% Natural } \\
\text { Gas }\end{array}$ & \% Coal & \% Nuclear & \% Hydro & \% Biomass & $\begin{array}{c}\text { Other } \\
\text { renewables\% }\end{array}$ \\
\hline 2000 & 36.4 & 20.9 & 22.8 & 6.7 & 2.4 & 10.3 & 0.5 \\
\hline 2005 & 34.9 & 20.5 & 25.3 & 6.3 & 2.4 & 10 & 0.6 \\
\hline 2010 & 32.3 & 21.5 & 27.2 & 5.6 & 2.5 & 10 & 0.9 \\
\hline 2015 & 31.3 & 21.6 & 28.1 & 4.9 & 2.5 & 10.1 & 1.5 \\
\hline 2016 & 31.8 & 21.9 & 27.2 & 5 & 2.5 & 9.9 & 1.7 \\
\hline 2017 & 30.6 & 22.6 & 26.9 & 4.9 & 2.8 & 9.8 & 2.4 \\
\hline
\end{tabular}

Despite a clear shift towards the use of renewable energy sources, this transition is very slow. Compared to 2000, there is a high consumption of coal and natural gas and a decrease in nuclear and hydropower consumption. Fossil energy, with all its emissions and environmental impacts, is therefore still the main source of energy in the world. Oil, coal and natural gas provides the core for the power structure and development of the global economy. The dominance of conventional energy sources is expected to continue in the short term, with expectations of a gradual shift in dependence on renewable energy sources over the long term. Table 2 shows the OPEC outlooks ${ }^{1}$ for global energy demand until 2040.

${ }^{1}$ One million tons of oil equivalent 
International Journal of Mathematical, Engineering and Management Sciences

Vol. 5, No. 6, 1032-1045, 2020

https://doi.org/10.33889/IJMEMS.2020.5.6.079

Table 2. Global energy demand forecasts until 2040

\begin{tabular}{|l|c|c|c|}
\hline Energy Source & $\mathbf{2 0 2 0}$ & $\mathbf{2 0 3 0}$ & $\mathbf{2 0 4 0}$ \\
\hline Oil & 4594 & 4896 & 5054 \\
\hline Natural Gas & 3388 & 4253 & 5149 \\
\hline Coal & 4188 & 4502 & 4632 \\
\hline Nuclear & 785 & 987 & 1186 \\
\hline Hydro & 385 & 451 & 501 \\
\hline Biomass & 1554 & 1752 & 1928 \\
\hline Other Renewables & 289 & 557 & 906 \\
\hline Total & 15184 & 17398 & 19356 \\
\hline Fossil Fuel Ratio & $80.20 \%$ & $78.40 \%$ & $76.60 \%$ \\
\hline Nuclear power ratio & $5.10 \%$ & $5.70 \%$ & $6.20 \%$ \\
\hline Other renewables ratio & $14.70 \%$ & $15.90 \%$ & $17.20 \%$ \\
\hline
\end{tabular}

There is still a long way to go towards a fundamental shift towards promoting sustainable energy consumption. It requires a strong desire to radically change the structure of your global energy consumption. In addition, many countries impose strict environmental policies on companies to reduce harmful gas emissions and conserve energy. The companies are the main energy consumer and, at the same time, the primary tool for achieving efficient energy consumption and the transition to sustainable energy use as part of the world's sustainable development policies. The optimal use of energy resources by companies means a shift from the traditional view of accounting as an information system interested in providing useful information for economic decision-making to a comprehensive multi-purpose system. It is essential that the accounting system be able to absorb various aspects of the organization 's activities, including energy issues, which require the development of an intellectual framework for energy accounting. In addition, the provision of information on the organization's consumption of various energy sources requires the development of energy accounting to accommodate the development of new accounting objectives, including emissions reduction, energy conservation and the promotion of sustainable energy. On the other hand, the applicable financial accounting standards can be developed to align with the goals of sustainable energy accounting in particular, the standards related to the measurement and reporting of energy resources. In this context, Su (2019) proposes three mechanisms for improving energy accounting:

1) Establish an appropriate legal system and the develop the standards of energy accounting.

2) Promote the theory of energy accounting and research.

3) Develop professional skills and improve the professional level of accountants.

\subsection{Sustainable Energy System}

Recently, it has been noted that the levels of consumption of different energy sources have increased in order to increase production, which leads to a random discharge of pollutants. The emission of pollutants into the atmosphere will not adversely affect the economic benefits of the company, but rather the reputation of the company for legitimacy in the society in which it operates. The companies should therefore set up an efficient energy accounting system that helps manage and control energy consumption, energy conservation and emission reduction. In addition, an efficient energy accounting system can contribute to a significant reduction in energy costs. Figure 2 shows the cost of generating electrical energy from different sources of energy, according to the estimates of the International Energy Organization. 
International Journal of Mathematical, Engineering and Management Sciences

Vol. 5, No. 6, 1032-1045, 2020

https://doi.org/10.33889/IJMEMS.2020.5.6.079

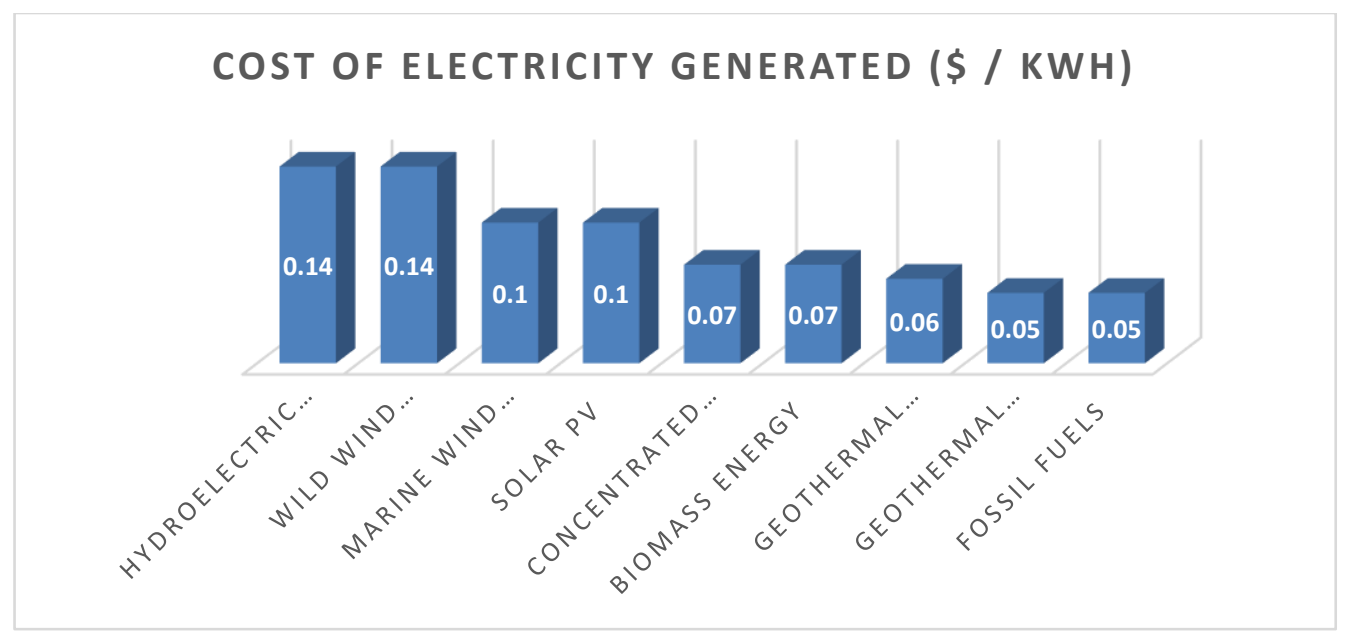

Figure 2. Average cost of electricity generated

The figure shows that the cost of producing electricity from renewable energy sources (wind and hydropower) is expensive. On the other hand, the failure of organizations to address energy conservation issues and reduce energy production costs means that they are eliminated, while economic knowledge and high competition are eliminated. Organizations should therefore set up energy accounting systems to help them control and manage energy consumption while at the same time seeking to reduce emissions and promote sustainable energy in the long term. The establishment of an effective energy accounting system helps organizations to achieve a balance between the economic objectives of maximizing profits on the one hand and the objectives of sustainable development on the other. Companies are no longer concerned only with direct costs of production, but are also concerned with all indirect costs associated with their environmental and social activities, which require a change in the accounting system of companies in order to adapt to this new trend.

\section{The Traditional Financial Reporting and Sustainable Development}

The traditional financial reporting process follows the accounting rules imposed by the relevant professional and government institutions, driven by the economic outlook, to increase profits as the primary objective of the accounting unit (Gray, 2006). The annual financial statements are therefore prepared in accordance with the measurement and disclosure requirements of the accounting profession, which are primarily designed to record transactions of a financial nature and to serve the objectives of the stakeholders (Almagtome and Abbas, 2020). Performance is typically measured by financial and productivity measures that are not effective in measuring performance, strategy and sustainability (Tangen, 2004). On the other hand, companies are under social and political pressure to uncover aspects of non-financial performance (Herremans et al., 2016). In this context, social pressures are increasing to make companies more transparent about sustainable development and reports on sustainable energy performance. The EU Directive on the disclosure of non-financial information and diversity is an example of these pressures aimed at increasing the transparency and accountability of companies on social and environmental issues (Al-Wattar et al., 2019). The accounting profession today closely interferes with the aims of the capitalist system, which is driven mainly by a desire to make profits. Current accounting methods and procedures have therefore been formulated primarily to measure profit and financial value only for organizations and large investors. 
International Journal of Mathematical, Engineering and Management Sciences

Vol. 5, No. 6, 1032-1045, 2020

https://doi.org/10.33889/IJMEMS.2020.5.6.079

Moreover, the current accounting system does not reveal any real social and environmental costs, such as emissions, pollution and negative social impacts of economic activity. In this regard, many accountants and investors are concerned about the inability of the traditional financial reporting system to provide the information needed to assess the performance of the organizations (Ong et al., 2010). It does not only consider financial information and neglects non-financial information that is material to measure the value of the company and non-financial risks (Serafeim, 2016). In addition, the traditional financial reporting system has been developed primarily for the industrial environment concerned with maximizing profits as a top value for the company. Although the current financial reporting system plays a key role in managing financial capital, it focuses on a narrow performance perspective that is historical performance expressed in monetary units only (Beck et al., 2017). Finally, it is necessary for the financial reporting system to comply with the requirements of sustainable development, as most organizations use natural resources to continue their activities, in particular sustainable energy sources. As a result, these organizations should develop a financial reporting system in place to prepare financial reports and adopt a more appropriate model for sustainable development requirements that can overcome the gaps in the traditional financial reporting system.

\section{Integrated Reporting Framework}

The 2008 global financial crisis is a turning point in corporate behavior towards the process of financial measurement and reporting and linking investment decisions to financial reporting in order to promote sustainable development and financial stability in the markets (Ali et al., 2019b). In addition, the increasing pressure on organizations to disclose the various performance measures has led to an increase in the number of reports submitted by these organizations. Investors' interest in non-financial information seemed to increase due to the positive impact of the sustainability and social responsibility reports on corporate behavior on issues of sustainable development and the promotion of ethical practices for organizations (Eccles and Serafeim, 2011). As a result, the International Integrated Reporting Council was established in 2010 and, one year later, the Integrated Reporting Framework was launched to develop the principles of integrated reporting (Havlová, 2015). The primary objective of this Council is to issue standards for the preparation of integrated reports for use by organizations around the world. The Integrated Reporting Framework aims to promote a change in the nature of financial reporting by issuing an integrated reporting guide that includes the definition of the business model and the creation of value and capital. This framework assumes that there is an urgent need to make a real change to the traditional accounting system that is currently in effect because it does not meet the needs of stakeholders by disclosing non-financial information. The Integrated Report is one of the relatively recent issues that have attracted the attention of organizations around the world and gained momentum over the last decade. The International Integrated Reporting Council defines the Integrated Report as "a process based on an Integrated Thinking that results in a periodic Integrated Report on Value Creation and Communication on Value Creation Aspects."

The content of the integrated report includes 8 basic elements covering the various aspects of the preparation of the report and its main elements of interest to investors, whether financial or nonfinancial information (Kılıç and Kuzey, 2018). According to IIRC (2013) the integrated report includes the following components:

1) Overview of The Organization and External Environment. The integrated report should provide a clear image of the vision of the organization, the main activity and the environment in which 
International Journal of Mathematical, Engineering and Management Sciences

Vol. 5, No. 6, 1032-1045, 2020

https://doi.org/10.33889/IJMEMS.2020.5.6.079

it operates.

2) Governance. The Integrated Report should provide adequate information on the governance structure of the organization and its ability to generate value in the short, medium and long term.

3) Business Model. The Integrated Report should provide information on the business model of the organization.

4) Risks and Opportunities. The Integrated Report should provide complete information on all the opportunities and risks that affect the ability of the company to generate value and how to deal with it in the long, medium and short term.

5) Strategy and Resource Allocation. The Integrated Report should provide complete information on the objectives of the organization and its strategy for managing resources.

6) Performance. The integrated report should provide sufficient information on the results of activities to achieve the strategic goals of the organization and its impact on capital.

7) Basis of Preparation and Presentation. The Integrated Report should contain information on the challenges and challenges facing the organization in order to achieve its objectives and the potential impact of the business model and the level of future performance.

8) General Reporting Guidance. The Integrated Report should contain a clear description of the preparation mechanism of the report and how the elements contained therein should be chosen and evaluated.

\section{Discussion: The Performance Indicators of Sustainable Energy}

Over the past three decades, many researchers have tried to develop accounting systems to track energy efficiency trends at the national economic level. The objective is to provide indicators to measure energy efficiency as a substitute for the GDP energy consumption indicator. This indicator is no longer suitable for measuring energy efficiency in the national economy. Over time, attempts continued to develop energy performance indicators that derive their data from national economy statistics and follow different methodologies by analogy. Most of these metrics are concerned with measuring performance at the national level. In accounting, progress has been made in developing accounting systems to report on performance, but these systems were suffering from differences in most respects, including methods of measurement and reporting on performance. The adoption of the integrated reporting framework enables accounting to standardize the basis for measurement and reporting on sustainable energy performance and helps to ensure transparency and consistency in reporting performance indicators.

Therefore, the current paper provides indicators to measure sustainable energy performance at the organization level, through which a full picture of sustainable energy performance can be presented. These indicators are based on the integrated reporting framework and consist of two types of indicators, financial and non-financial indicators. The indicators can be disclosed within the 
International Journal of Mathematical, Engineering and Management Sciences

Vol. 5, No. 6, 1032-1045, 2020

https://doi.org/10.33889/IJMEMS.2020.5.6.079

performance section in the integrated report. The proposed performance indicators of sustainable energy consist of financial and non-financial indicators. The explanations for the proposed energy performance indicators are shown in Table 3.

Table 3. Summary of performance indicators of sustainable energy

\begin{tabular}{|c|c|c|c|}
\hline Type & Acronym & Performance Indicator & Explanations \\
\hline \multirow{8}{*}{$\begin{array}{l}\text { Financial } \\
\text { Indicators }\end{array}$} & TEC & Total Energy Costs & Total costs of energy consumed in all activities \\
\hline & PEC & Production Energy costs & Total costs of energy consumed in production activities \\
\hline & TECS & Saving in total energy costs & The saving in the total energy costs \\
\hline & PECS & $\begin{array}{l}\text { saving in production energy } \\
\text { costs }\end{array}$ & The saving in the production energy costs \\
\hline & EI & Energy investments & $\begin{array}{l}\text { Total investment costs in machines, equipment, and supplies of } \\
\text { energy system }\end{array}$ \\
\hline & REI & $\begin{array}{ll}\text { Renewable } & \text { Energy } \\
\text { investments } & \\
\end{array}$ & The total amount of renewable energy investment \\
\hline & EI & Energy efficiency & Total energy costs per output unit (product or service) \\
\hline & RE & Remediation efforts & The costs of Remediation efforts \\
\hline \multirow{8}{*}{$\begin{array}{l}\text { Nonfinancial } \\
\text { Indicators }\end{array}$} & $\mathrm{EC}$ & Energy consumption & $\begin{array}{l}\text { The quantity of the energy consumed in production, according } \\
\text { to the energy type consumed in the organization such as oil, } \\
\text { coal, natural gas, etc. }\end{array}$ \\
\hline & EM & Emissions & The quantity and type of the pollutants \\
\hline & TEI & Traditional Energy intensity & Percent of traditional energy to total energy consumed \\
\hline & REI & $\begin{array}{l}\text { Renewable energy } \\
\text { efficiency }\end{array}$ & $\begin{array}{l}\text { Renewable energy consumed as a percentage of total energy } \\
\text { consumption. }\end{array}$ \\
\hline & TEC & Total Energy conservation & The quantity of total energy saving \\
\hline & PEC & $\begin{array}{ll}\text { Production } & \text { Energy } \\
\text { conservation } & \\
\end{array}$ & The quantity of total energy saving \\
\hline & EMS & Energy management system & $\begin{array}{l}\text { The adoption of an energy management system in accordance } \\
\text { with ISO } 50001\end{array}$ \\
\hline & REP & Renewable energy projects & $\begin{array}{l}\text { Firm involvement in renewable energy projects. It is a } \\
\text { percentage calculated by dividing the amount of investment in } \\
\text { the project on the total assets of the organization }\end{array}$ \\
\hline
\end{tabular}

The sustainable energy performance indicators proposed in this paper can be illustrated as follows:

\section{1) The Financial Indicators}

Financial indicators consist of 8 measures and can be calculated using the outputs of the accounting system and can be disclosed in the integrated report of the company. These indicators include the following:

- Total Energy Costs (TEC). This indicator measures the size of the energy consumption of the organization as measured by the monetary unit. It is calculated from the collection of energy costs consumed in all the activities of the organization from the accounting books during the year. Energy costs should be disclosed in detail, indicating the costs of each energy item.

- Production Energy Costs (PEC). This indicator measures the costs of all types of energy consumed in production activity only during the year. This indicator is calculated compiling the costs of production energy of various kinds, whether it is electricity or oil. Natural gas etc.

- Saving in Total Energy Costs (TECS). This indicator measures the efficiency of the organization's energy costs management and control. It is measured by the amount of savings of energy costs incurred in all the activities of the organization. 
International Journal of Mathematical, Engineering and Management Sciences

Vol. 5, No. 6, 1032-1045, 2020

https://doi.org/10.33889/IJMEMS.2020.5.6.079

- Saving in Production Energy Costs (PECS). This indicator measures the efficiency of the organization's management and control of production energy costs. It is calculated by the difference between the total energy costs consumed in the production activity in the beginning and ending of the year.

- Energy Investments (EI). This indicator measures the organization's efficiency in energy management as well as the amount of spending on investment devices and equipment to improve energy efficiency.

- Renewable Energy Investments (REI). This indicator measures the efficiency of the organization in the field of sustainable energy management. It is calculated by collecting investment costs for renewable energy generation appliances and equipment, such as solar cells, wind, and others.

- Energy Efficiency (EI). This indicator measures the energy efficiency of the organization and its success in reducing energy consumption in the production. It is calculated by dividing the total cost of energy by the number of units of output and therefore measures the cost of energy per unit of output, whether products or services.

- Remediation Efforts (RE). This indicator measures the efforts made by the organization to deal with environmental damage caused by energy consumption, such as emissions or leakage of fuel used in production. It is calculated by summing up the costs of health and environmental damage treatment activities for energy consumption, such as treatment of emissions, treatment of oil and fuel leakage, health damage to workers, etc.

\section{2) The Nonfinancial Indicators}

Nonfinancial indicators consist of 8 measures and can be identified using the outputs of accounting and management information systems and can be disclosed in the integrated report of the company. These indicators include the following:

- Energy Consumption (EC). This indicator measures energy efficiency in a quantitative way, which varies depending on the variety of energy sources used in production. It refers to the amount of energy consumed by the organization and is measured in non-monetary units such as $\mathrm{kg}$, liters, kilowatts, etc.

- Emissions (EM). This indicator measures the amount of pollutants emitted by energy consumption. It is calculated in units of carbon dioxide emitted into the air. This indicator reflects the organization's efficiency in controlling emissions and reducing fuel consumption pollution.

- Traditional Energy Intensity (TEI). This indicator measures the organization's dependence on conventional sources of energy. It is calculated by dividing the cost of traditional energy consumed by the total cost of energy. This indicator reflects the organization's efficiency in reducing fossil energy consumption and shifting towards the adoption of renewable energy sources.

- Renewable Energy Efficiency (REE). This indicator measures the organization's dependence on renewable energy sources. It is calculated by dividing the cost of renewable energy 
International Journal of Mathematical, Engineering and Management Sciences

Vol. 5, No. 6, 1032-1045, 2020

https://doi.org/10.33889/IJMEMS.2020.5.6.079

consumed by the total cost of energy. This indicator reflects the organization's efficiency in reducing fossil energy consumption and shifting towards the adoption of renewable energy sources.

- Total Energy Conservation (TEC). This indicator measures the amount of savings in the total energy consumed by the organization. It is calculated by comparing the difference between the amount of energy consumed in the current year and the amount of fuel consumed in the prior year. This indicator reflects the efficiency of the organization's energy management and its ability to streamline the consumption of available energy resources.

- Production Energy Conservation (PEC). This indicator measures the amount of energy savings consumed in production activities only. It is calculated by comparing the difference between the amount of energy consumed in the production departments in the current year and the amount of fuel consumed in the previous year. This indicator reflects the efficiency of the organization's energy management and its ability to streamline the energy resource consumption available for the production process.

- Energy Management System (EMS). This indicator shows the efficient management of the organization's energy resources. If the organization applies the energy management system in accordance with ISO 50001, the value of the indicator is 100 percent and vice versa, the value of the indicator is zero.

- Renewable Energy Projects (REP). This indicator indicates the efficiency of the organization in managing sustainable energy sources through participation in renewable energy development projects. It is calculated by dividing the total amount of investments in sustainable energy development projects by the total assets of the organization.

\section{Summary and Conclusions}

The implementation of the Integrated Reporting Framework represents a fundamental change in the corporate philosophy of financial reporting. It is concerned with providing past, current and future information to create value within the organization. The information disclosed in the Integrated Report relates to the organization's strategy for managing its financial, intellectual, human, social and natural resources. The focus on the conservation of natural resources, particularly energy sources, has prompted many countries to adopt sustainable development strategies that aim to sustain their economic activity and conserve energy sources in the long term. Energy accounting is one of the modern branches of accounting that draws ideas and working mechanisms from the theories of economics as well as the accounting rules and procedures applied in traditional accounting systems. However, the role of traditional accounting systems in promoting sustainable development in general and sustainable energy management in particular is limited. The reason for this is that the outputs of the accounting system are limited to financial information only, whereas sustainable development requires the provision of financial and non-financial information. The paper also aims to explore the integrated reporting framework, the most important elements of the integrated report and the nature of the information to be disclosed in the report. The aim of this paper is to develop indicators for measuring sustainable energy performance using the integrated reporting framework. Similar to (De Villiers et al., 2014; Dumay et al., 2017; Machado Junior et al., 2017) this paper uses a systematic analytical approach based on the literature on energy accounting, in addition to the preparation of integrated performance measurement reports using financial and non-financial performance information in the consolidated report. The current paper proposed 16 sustainable energy 
International Journal of Mathematical, Engineering and Management Sciences

Vol. 5, No. 6, 1032-1045, 2020

https://doi.org/10.33889/IJMEMS.2020.5.6.079

performance indicators, divided into 8 financial performance indicators and 8 non-financial performance indicators. The adoption of an Integrated Reporting Framework allows organizations to expand the scope of the Sustainable Energy Performance Indicators proposed in this paper within the performance section of the Integrated Report. The results of this paper provide a better understanding of accountants, managers, investors and general stakeholders on the mechanism for preparing an integrated report and the most prominent performance indicators for sustainable energy at the organization level. Furthermore, the application of the indicators proposed in this paper helps regulators and economic policy makers to draw up sustainable development strategies at national level as well as to provide accurate information on the real and future of sustainable energy in the country.

\section{Conflict of Interest}

The authors confirm that there is no conflict of interest to declare for this publication.

\section{Acknowledgments}

The authors express their appreciation to the colleagues who reviewed this paper and offered useful recommendations for improving it. The authors greatly appreciate the time and useful suggestions from guest editors and reviewers.

\section{References}

Ali, M., Almagtome, A., \& Hameedi, K. (2019a). Impact of accounting earnings quality on the going-concern in the Iraqi tourism firms. African Journal of Hospitality, Tourism and Leisure, 8(5), 1-12.

Ali, M., Hameedi, K., \& Almagtome, A. (2019b). Does sustainability reporting via accounting information system influence the investment decisions in Iraq? International Journal of Innovation, Creativity and Change, 9(9), 294-312.

Almagtome, A., \& Abbas, Z. (2020). Value relevance of financial performance measures: an empirical study. International Journal of Psychological Rehabilitation, 24(7), 6777-6791.

Almagtome, A., Shaker, A., Al-Fatlawi, Q., \& Bekheet, H. (2019). The integration between financial sustainability and accountability in higher education institutions: an exploratory case study. International Journal of Innovation, Creativity and Change, 8(2), 202-221.

Al-Wattar, Y.M.A., Almagtome, A.H., \& AL-Shafeay, K.M. (2019). The role of integrating hotel sustainability reporting practices into an accounting information system to enhance hotel financial performance: evidence from Iraq. African Journal of Hospitality, Tourism and Leisure, 8(5), 1-16.

Ang, B.W., Mu, A., \& Zhou, P. (2010). Accounting frameworks for tracking energy efficiency trends. Energy Economics, 32(5), 1209-1219.

Beck, C., Dumay, J., \& Frost, G. (2017). In pursuit of a 'single source of truth': from threatened legitimacy to integrated reporting. Journal of Business Ethics, 141(1), 191-205.

De Villiers, C., Unerman, J., \& Rinaldi, L. (2014). Integrated Reporting: Insights, gaps and an agenda for future research. Accounting, Auditing \& Accountability Journal, 27(7), 1042-1067.

Dumay, J., Bernardi, C., Guthrie, J., \& La Torre, M. (2017). Barriers to implementing the international integrated reporting framework. Meditari Accountancy Research, 25(4), 461-480.

Eccles, R.G., \& Serafeim, G. (2011). Accelerating the adoption of integrated reporting. CSR INDEX, Francesco de Leo, Matthias Vollbracht, eds.: InnoVatio Publishing Ltd.. 
International Journal of Mathematical, Engineering and Management Sciences

Vol. 5, No. 6, 1032-1045, 2020

https://doi.org/10.33889/IJMEMS.2020.5.6.079

Goh, T., \& Ang, B. (2019). Comprehensive economy-wide energy efficiency and emissions accounting systems for tracking national progress. Energy Efficiency, 12(8), 1951-1971.

Gray, R. (2006). Social, environmental and sustainability reporting and organisational value creation? Accounting, Auditing \& Accountability Journal, 19(6), 793-819.

Havlová, K. (2015). What integrated reporting changed: the case study of early adopters. Procedia Economics and Finance, 34, 231-237.

Herremans, I.M., Nazari, J.A., \& Mahmoudian, F. (2016). Stakeholder relationships, engagement, and sustainability reporting. Journal of Business Ethics, 138(3), 417-435.

Hong, J., Gu, J., Liang, X., Liu, G., \& Shen, G.Q. (2019). Characterizing embodied energy accounting with a multi-dimensional framework: a study of China's building sector. Journal of Cleaner Production, 215, 154-164.

IIRC. (2013). The international< IR> framework. IR Council: Zurich, Switzerland.

Karstensen, K.H., Engelsen, C.J., \& Saha, P.K. (2020). Circular economy initiatives in Norway. In Circular Economy: Global Perspective (pp. 299-316): Springer, Singapore.

Khaghaany, M., Kbelah, S., \& Almagtome, A. (2019). Value relevance of sustainability reporting under an accounting information system: evidence from the tourism industry. African Journal of Hospitality, Tourism and Leisure, 8(Special Edition CUT), 1-12.

Kılıç, M., \& Kuzey, C. (2018). Assessing current company reports according to the IIRC integrated reporting framework. Meditari Accountancy Research. 26(2), 305-333.

Kravchenko, M., McAloone, T.C., \& Pigosso, D.C. (2019). Implications of developing a tool for sustainability screening of circular economy initiatives. Procedia CIRP, 80, 625-630.

Machado Junior, C., César, R.D.D.S., \& Souza, M.T.S.D. (2017). Adherence of private health system hospitals to dissemination of outcomes according to the Global Reporting Initiative (GRI) model. Einstein (São Paulo), 15(3), 344-348.

Mangla, S.K., Luthra, S., Jakhar, S., Gandhi, S., Muduli, K., \& Kumar, A. (2020). A step to clean energySustainability in energy system management in an emerging economy context. Journal of Cleaner Production, 242, 118462.

Ong, G.P., Sinha, K.C., \& Fwa, T.F. (2010). Strategies for achieving sustainability through integrated transportation and urban development in the USA and Asia. Asian Transport Studies, 1(1), 89-104.

Rehman Khan, S.A., \& Yu, Z. (2020). Assessing the eco-environmental performance: an PLS-SEM approach with practice-based view. International Journal of Logistics Research and Applications, 1-19. doi: 10.1080/13675567.2020.1754773.

Serafeim, G. (2016). Integrated reporting-statement on management accounting. Institute of Management Accountants, 31 .

Su, R. (2019, December). Research on energy accounting under energy conservation and emission reduction policies. In IOP Conference Series: Materials Science and Engineering (Vol. 677, No. 3, p. 032113). IOP Publishing. Melbourne, Australia.

Tangen, S. (2004). Performance measurement: from philosophy to practice. International Journal of Productivity and Performance Management, 53(8), 726-737.

Original content of this work is copyright (c) International Journal of Mathematical, Engineering and Management Sciences. Uses under the Creative Commons Attribution 4.0 International (CC BY 4.0) license at https://creativecommons.org/licenses/by/4.0/ 